\author{
Elena A. Lisichenok, Igor A. Prohorenkov \\ (Institute of History of St. Petersburg State University, St. Petersburg, Russia)
}

\title{
The Oriental discourse in the anti-Moscow Posiłek Bellony słowieńskiej by Marcin Paszkowski ${ }^{1}$
}

Dyskurs orientalny w antymoskiewskim utworze Marcina Paszkowskiego „Posiłek Bellony słowieńskiej”

\section{STRESZCZENIE:}

Marcin Paszkowski to poeta znany przede wszystkim dzięki swoim pracom związanym z Turcją. Jednak w jego twórczości możemy spotkać wiele innych wątków. Artykuł ma pokazać, jak orientalna tematyka wpływała na twórczość poety na przykładzie jego utworów antymoskiewskich.

Słowa kluczowe: Marcin Paszkowski, orientalizm, Turcyki

Marcin Paszkowski is an obscure Polish poet of the period at the turn of the XVI into the XVII century, who might hold an appeal not only by his works, but also because facts and fiction in his biography are so interwoven that the researchers still have not been able to distinguish between them. It is even possible to claim that in almost every field of the humanities there is its own Marcin Paszkowski. He is regarded as the poet by philologists, as the author of one of the first Turkish-Polish dictionary by linguists, as the co-author of the chronicle by Alexander Guagnini and a genuine colleague by historians, yet the data about him is so disparate that the researchers sometimes suppose that there existed several people under the name of Marcin Paszkowski². It was only recently that thanks to the information meticulously gathered by Professor Michał Kuran in his remarkable work Marcin Paszkowski - poeta okolicznościowy i moralista

${ }^{1}$ The work was supported by the Russian Foundation for Humanities, the project № 15-21-01003 a(m).

2 S. Załęski, Jezuici w Polsce, Lwów 1901, t. 2, 695, 705-706. 
z pierwszej połowy XVII wiek $u^{3}$ that the myths connected with this poet were dispelled and his biography was generally reconstructed.

However, judging by the historiography about Marcin Paszkowski it is necessary to conclude that the success in the analysis of his works and life cannot be achieved without allied research methods. In other words, philologists, linguists and historians have to join forces. This article will illustrate a fascinating interdisciplinary aspect in the works by Marcin Paszkowski: the particuliarites of the constructing of enemy images in his anti-Moscow works. The article, which is partly based on the results of the textological analysis by Professor Kuran, will demonstrate how the integration between philological and historical approaches gives new insight into the poems by Marcin Paszkowski.

One of the most significantly inaccurate facts, which until recently has been often referred to and repeated in different scholarly articles, has to do with so-called ",oriental" or „Turkish" version of the biography of Marcin Paszkowski. The main reason for this is the following: the researchers basing on the notes by the authors of the encyclopedias of the XVIII-XIX cc. and taking into the consideration the poet's interest in Turkish subjects, believed that Marcin Paszkowski either was a missionary in Ukraine, where he had regular contacts with the Turks, or visited Istanbul, as an envoy or as a captive.

Thanks to the historiography gathered by M. Kuran, it is possible to understand where these misconceptions stem from. The first one who mentioned that the poet belonged to the Society of Jesus was the Archbishop of Gniezno Ignacy Krasicki (1735-1801), who wrote about it in his encyclopedia, not indicating the source of his information ${ }^{4}$. Afterwards a French scholar Carlos Sommervogel followed suit describing Paszkowski as an Ukrainian (Little Russian) missionary ${ }^{5}$. This unconfirmed version later on was taken for granted by other researchers ${ }^{6}$.

${ }^{3}$ M. Kuran, Marcin Paszkowski - poeta okolicznościowy i moralista z pierwszej połowy XVII wieku, Łódź 2012.

${ }^{4}$ I. Krasicki, Zbior potrzebniejszych wiadomości, porzadkiem alfabetu ułożonych, Warszawa-Lwów 1781, t. 2, 327.

${ }^{5}$ C. Sommervogel, Bibliothèque de la Compagnie de Jesus: nouvelle edition par Carlos Sommervogel SJ. Bibliographie, Bruxelles-Paris 1895, t. 6, 342

${ }^{6}$ For example: 1) А. Ю. Мицик, Початки Польськоі держави за хронікою Олександра Гваньіні, „Пам 'ятки. Археографічний щорічник”, 2005, 5, 53-84. 2) В. М. Пилипенко, Антитурецький дискурс в похітичній думиз Речі Посполитої середини XVI - середини XVII cm., автореферат дисертації... кандидата історичних наук: 07.00.02, Київ 2009. 3) 
Other scholars perceived Marcin Paszkowski, first and foremost, as a poet of Oriental theme. With regard to it, the author of The library of obscure Polish poets and writers ${ }^{7}$ Teodor Wierzbowski suggested a new approach to the biography of Paszkowski. He claimed that the authorship of the anti-Turkish poem-chronicle Venice (1575) by Krzysztof Warszewicki could easily be attributed to Marcin Paszkowski ${ }^{8}$. He put forward the following arguments: firstly, this poem was devoted to Walenty Dembiński, with whose family Marcin Paszkowski maintained close relationships; secondly, its style was similar to the other works by Paszkowski. Developing his idea, the scholar wondered why Marcin Paszkowski, having written the poem, kept silence for nearly thirty years before resuming his literary activities only in 1608. However strange it might seem, Wierzbowski used this time gap in favour of his theory. According to him, the poet either took part in the diplomatic mission of Andrzej Tarnowski in Turkey, or was a member of the expedition of Mikołaj Mielecki to Walachia. As a result of either of the expedition, Marcin Paszkowski was captured and spent thirty years in captivity in Turkey. The experience gained there and his personal ideas of revenge encouraged him to resort to anti-Turkish publicistic writing after being liberated. However, this theory is based entirely on the researcher's logical deductions and is not confirmed by anything else.

The "Oriental" version of the biography of Marcin Paszkowski has a striking feature: being very ill-grounded compared to others, it still remains the most widespread. For example, this theory is quite popular in Ukrainian historiography, where Marcin Paszkowski is directly called an Ukrainian poet, who happened to find himself in Poland by chance.

One way or another, it is undeniable that Marcin Paszkowski took a genuine interest in the East, to be exact - in the image of the Orient. It should be noted that he might not have ever been either in Ukraine or in Turkey. He may have been an "armchair" orientalist as, according to the recent findings, it is quite likely that he never had any contacts with Turkish native speakers and hardly had any command of the Turkish language himself 9 .

Ref. the translations of Paszkowski's texts by Ukrainian writer Valerij A. Shevchuk.

${ }^{7}$ T. Wierzbowski, Biblioteka zapomnianych poetów i prozaików polskich XVI-XVIII wieku, Warszawa 1886.

${ }^{8}$ Wstęp, Wenecyja. Poemat historyczno-polityczny z końca XVI wieku, wyd. T. Wierzbowski, Warszawa 1886, p. V; T. Wierzbowski, Biblioteka..., XXXIX.

${ }^{9}$ M. Stachowski, Marcin Paszkowski's Polish and Turkish dictionary (1615), „Studies in Polish Linguistics" 2013, 8, 1, 50. 
Yet Oriental themes manifest themselves not only in the anti-Turkish poems. This leads us to the topic of the article - to the analysis of antiMoscow works by Marcin Paszkowski.

There are three interesting works by the poet which can be referred to as anti-Moscow works: Wykład bogin stowieńskich... [= The tale of Slavic goddesses... $]^{10}$, Posiłek Bellony słowieńskiej szlachetnemu rycerstwu Dymitra Iwanowicza... [= The reinforcement of Slavic Bellona to the noble chivalry of Dmitry Ivanovich... $]^{11}$ and a short rhymed note from the chronicle by Alexander Guagnini Opisanie wzięcia Smoleńska... [= The description of the siege of Smolensk $]^{12}$. Although these three works are devoted to different subjects, they are thematically united by the idea of inner strengthening of the Polish-Lithuanian Commonwealth (this plot is well-developed in the poem Wykład bogin stowieńskich... which centers round Zebrzydowski's Rebellion) and the military expansion to the East. The Muscovite state is not merely the aim of the expansionist policies of Marcin Paszkowski he suggests solving Poland's inner problems at the expense of its eastern neighbor. Why do noble knights shed blood fighting with each other when they can join forces and turn against the Muscovite despot in a glorious campaign? this is the central idea of his poem Posiłek Bellony stowieńskiej szlachetnemu rycerstwu Dymitra Iwanowicza.... This work will be analyzed in depth.

The poem, which was published in two recensions in $1608^{13}$, was textologically analyzed quite well by M. Kuran. Nevertheless, where the task of a philologist ends, the task of a historian starts. The author of the study Marcin Paszkowski... demonstrated clearly that the poem Positek Bellony słowieńskiej... could hardly be called original as it was literally borrowed from the works by Maciej Stryjkowski and Sebastian Fabian Klonowic. In other words, at the beginning of his literary career Marcin Paszkowski plagiarised other writers' texts. For a literary critic such facts substantial-

${ }^{10}$ M. Paszkowski, Wykład bogiń słoweńskich, wesołego widzenia słonca z Panna, w złotym kole nad Krakowem: roku Pańskiego 1608, maja dnia 30, przedruk fragm, [w:] Pisma polityczne z czasów rokoszu Zebrzydowskiego 1606-1608, wyd. J. Czubek, t. 1: Poezja rokoszowa, Kraków 1916, 337-342.

${ }^{11}$ Idem, Posiłek Bellony słowieńskiej szlachetnemu rycerstwu Dymitra Iwanowicza W[ielkiego] Cara Moskiewskiego przeciwko Sujskiemu i inszym zdrajcom jego, Kraków 1608.

${ }^{12}$ A. Guagnini, Kronika Sarmacyey Europskiey, w ktorey sie zamyka krolestwo Polskie...... Tudziez tez Wielkie Xiestwo Litewskie, Ruskie, Pruskie, Zmudzkie, Inflantskie, Moskiewskie y czesc Tatarow..... z Lacinskiego na Polskie przelozona (par Marcin Paszkowski), Krakow 1611, ks. 7, cz. $4,80-81$.

${ }^{13}$ The poem was published in 1611 in two versions. The poet failed to find a patron for his first recension, so in August 1611 Paszkowski published a second version dedicating it to such prominent figures as, for example, a Polish envoy Mikołaj Oleśnicki, who had just returned from Moscow's captivity. For more on recensions see: M. Kuran, op. cit., 155-158. 
ly diminish the importance of the author's heritage, that is why Marcin Paszkowski is often dubbed a mediocre and second-rate writer in many reference books ${ }^{14}$. The historian's viewpoint with regard to this issue may differ dramatically and it can be illustrated by Paszkowski's poem Positek Bellony stowieńskiej... It will be proved in this article that to a historian the direct dependence of Paszkowski's text on the works by his more prominent colleagues-poets may seem as perhaps one of its main merits.

Since the first quarter of the XV century (we refer to the period and works by Mikołaj Lasocki as a starting point) there had been formed a certain genre of anti-Turkish writing in the Polish literature - so called turcyki. By the time Paszkowski reached his peak, the stylistic devices of this genre had been elaborately developed by such renowned writers as Stanisław Orzechowski, Krzysztof Warszewicki, Bartołomiej Paprocki and others ${ }^{15}$.

As it has already been mentioned, Paszkowski in his poem Positek Bellony słowieńskiej... tries to imitate a famous poet and anti-Turkish publicist S. F. Klonowic, who worked at the end of the XVI - the beginning of the XVII century, and also borrows material from the works by one of the leading historiographers of the Grand Duchy of Lithuania, Maciej Stryjkowski. Having borrowed a substantial amount of text from Klonowic's turcyka Pożar wojny tureckiej [The fire of Turkish war ${ }^{16}$ and from Maciej Stryjkowski's genealogical poem Goniec cnoty... [The messenger of virtue...] ${ }^{17}$ , Marcin Paszkowski makes an original step - using the stylistic canon of turcyka, he writes an anti-Moscow work. In other words, he managed to use anti-Turkish format for anti-Moscow content, thus proclaiming the likeness between both states.

The issue of the status of the Moscovite state had been of interest to the Polish intellectuals long before Marcin Paszkowski. There had been a number of opinions about the eastern neighbour ${ }^{18}$ : from acknowledging

${ }^{14}$ Pisma polityczne z czasów rokoszu Zebrzydowskiego, 1606-1608, wyd. J. Czubek, t. 1: Poezya rokoszowa, Kraków 1916, 337.

${ }^{15}$ A. Danti, "Utopijny" aspekt literatury antytureckiej we Włoszech $i$ w Polsce w połowie XVI wieku, [w:] Od "Lamentu świętokrzyskiego" do "Adona". Włoskie studia o literaturze staropolskiej, red. G. Brogi Bercoff, T. Michałowska, Warszawa 1995, 117-138.

${ }^{16}$ S. F. Klonowic, Pożar wojny Tureckiej. Upominanie do gaszenia i wróżka o upadku mocy tureckiej, [b. m.] 1597. Przedr. Dzieła Fabiana Sebestyana Klonowicza, wyd. J. N. Bobrowicz, Lipsk 1836, t. II, 137-158.

${ }^{17}$ M. Stryjkowski, Goniec cnoty do prawych slachciczow w którym sa przykłady spraw mężow zacnych. Przytym napominanie Oyczyzny ku prawdziwym synom, Kraków 1574.

${ }_{18}$ Д. В. Карнаухов, Moshi unde: развитие представлений о происхождении «московского народа» в польской историографии эпохи Возрождения, „Гуманитарные науки в Сибири", 2009, 2, 10-14. 
Moscow as "the younger brother" of the Polish and Czech states to the theory of its independent origin. Nonetheless, most authors admitted the possibility of cultural dialogue. Marcin Paszkowski's viewpoint was far more radical: his choice of a turcyka as a form of narrative had to demonstrate to the readers that Moscow was no different from Turkey and it was impossible to maintain any other relationships with Moscow but from the position of strength. The fate of the troublesome eastern neighbour was clear to the poet - Moscow had to be conquered and civilized by the more developed Polish-Lithuanian Commonwealth.

Therefore, Marcin Paszkowski's poem Positek Bellony słowieńskiej... can be regarded as an excellent example of the text with Oriental discourse. The work by Paszkowski will be analysed on the basis of the research methodology developed in the fundamental studies by Edward Said ${ }^{19}$ and Larry Wolff ${ }^{20}$ as most suitable for the above mentioned poem ${ }^{21}$. As far as those principles are concerned, the following features of Paszkowski's text can be pinpointed:

1) The primary task for Paszkowski is to convince the readers that the Turkish and the Moscovite threats are similar. In order to achieve his aim he resorts to a familiar to the contemporaries form of anti-Turkish publicist writing - turcyka. For the purpose of our research it is more important to understand not what he borrowed from other texts, but what he added to them. For example:

\begin{tabular}{|l|l|}
\hline \multicolumn{1}{|c|}{ Klonowic, Pożar wojny Tureckiej } & \multicolumn{1}{c|}{ Paszkowski, Posiłek Bellony stowieńskiej... } \\
\hline $\begin{array}{l}\text { Niech na trąbienie upadnie tyrańska } \\
\text { Władza a sceptrum, i moc Ottomańska } \\
\text { (stanza 435-436) }\end{array}$ & $\begin{array}{l}\text { Tak niech upadnie ta władza tyrańska, } \\
\text { Zdrajców Moskiewskich, i srogość pogańska } \\
\text { (stanza 5-8) }\end{array}$ \\
\hline
\end{tabular}

Paszkowski repeatedly borrowed fragments of texts from other authors changing just a few words there. It is these words that we consider to be of crucial importance: Paszkowski kept the whole anti-Turkish text, only making such changes as ,Turkish = Moscovite", "Sultan = Tsar", "Muslims = schismatics/pagans" etc. Most often it was the Moscovite ruler who came into his criticism:

\footnotetext{
${ }^{19}$ E. Said, Orientalism, New York 1978.

${ }^{20}$ L. Wolff, Inventing Eastern Europe: the Map of Civilization on the Mind of the Enlightenment, Stanford 1994.

${ }^{21}$ We refer to two basic strategies used by Western authors in the descriptions of the Orient: the construction of the image of barbarian, which imposed to the described nation, and the development of European identity through the comparison of Western people with this barbarian.
} 


\begin{tabular}{|l|l|}
\hline \multicolumn{1}{|c|}{ Klonowic, Pożar wojny Tureckiej } & \multicolumn{1}{|c|}{ Paszkowski, Posiłek Bellony słowieńskiej... } \\
\hline Nie może pozbyć Boga, lecz straszliwe & Nie mogąc pozbyć Boga żądzej wieści, \\
Baśni mieszając, powieści prawdziwe & Baśni mieszając, prawdziwe powieści \\
Pieje: tak mnie też Muza prze do tego, & Pieje: tak mnie też Muza prze do tego, \\
Bym pisal klęskę tyrana Thrackiego. & Bym glosil zdrajcy upadek Szujskiego. \\
(stanza 23-26) & (stanza 20-24) \\
\hline
\end{tabular}

Obviously, the Turkish sultan and the Muscovite tsar in Paszkowski's poem were predictably doomed:

\begin{tabular}{|l|l|}
\hline \multicolumn{1}{|c|}{ Klonowic, Pożar wojny Tureckiej } & \multicolumn{1}{|c|}{ Paszkowski, Positek Bellony stowieńskiej... } \\
\hline Coby rzekt albo pomyślyt potomny & Coby rzekt albo pomyślyt potomny \\
Naród, że na tym miejscu on ogromny & Naród, że na tym miejscu on ogromny \\
Turczyn porażon, tu zastęp szalony, & Szujski porażon, tu zastęp szalony, \\
Co z BOGIEM walczyl, sprośnie położony & Co z Carem walczyt, sprośnie położony. \\
(stanza 556-560) & (stanza 272-276) \\
\hline
\end{tabular}

2) Marcin Paszkowski's poem mainly centres round the figure of the tsar. It should be noted that the poem came out in 1608 and was supposed to inspire the Polish nobility to support Dmitry Ivanovich, the Muscovite tsar, against Shuysky and other traitors. If there was no need for a Polish aristocrat to justify the military campaign to Turkey, Moscow represented a different case and Paszkowski was fully aware of it. That was why he decided to rationalise the necessity of a military action against Moscow resorting to the terms of a well-developed medieval ,just war" theory. The real tsar is in Poland whereas Moscow is taken by an outrageous self-proclaimed tyrant and his henchmen - why don't noble knights lend a helping hand to the lawful ruler?

\begin{tabular}{|l|l|}
\hline \multicolumn{1}{|c|}{ Klonowic, Pożar wojny Tureckiej } & \multicolumn{1}{|c|}{ Paszkowski, Posiłek Bellony stowieńskiej... } \\
\hline Oto choragiew fenrycha zacnego, & Oto choragiew Cara prawdziwego, \\
Oto brzmi trąba Chrysta lwa mocnego. & Oto brzmi traba głosnej sławy jego. \\
Ubiegajciesz się Rycerze cnotliwi & Ubiegajciesz się Rycerze cnotliwi \\
Pod ten proporzec do potkania chciwi & Pod ten choragiew do potkania chciwi \\
(stanza 53-56) & (stanza 49-52) \\
\hline
\end{tabular}

Upon reading the poem an inexperienced reader can feel perplexed: Paszkowski suggests assisting the lawful tsar to reclaim his throne and at the same time calls for "shedding blood" of his subjects and flooding the whole Muscovite state in it! 


\begin{tabular}{|l|l|}
\hline \multicolumn{1}{|c|}{ Klonowic, Pożar wojny Tureckiej } & \multicolumn{1}{|c|}{ Paszkowski, Posiłek Bellony słowieńskiej... } \\
\hline Niechaj karmi zwierz i ptatstwo łakome, & Niechaj karmi zwierz i ptatstwo łakome, \\
Od Chreścijanów wojsko porażone. & Od was złej Orze wojsko porażone. \\
Niech się czerwienią doły i potoki, & Niech się czerwienią doły i potoki, \\
Od krwie Tureckiej, od zsiadłej posoki. & Od krwie moskiewskiej, od zsiadłej posoki. \\
(stanza 53-56) & (stanza 253-256) \\
\hline
\end{tabular}

However, it is all perfectly logical in Paszkowski's work. The poem condemns the political system of Moscow in contrast to the Polish-Lithuanian Commonwealth ${ }^{22}$ : barbaric tyranny versus flourishing republic, eastern slavery versus European liberties and rights, avaricious and cunning boyars versus virtuous and honourable knights. Even the people of Moscow are inferior, according to Paszkowski - they are called the Sarmatians' stepchildren unlike the Poles who are lineally descended from the glorious nomadic tribes.

In other words, it is stressed that oriental Moscovite state is in need of radical transformation. Tsar Dmitry Ivanovich as the representative of the Western culture is the person who is able to do it, only with the help of the Polish gentry. Paszkowski's poem suggests a real plan of colonizing a backward eastern neighbour by a more developed Polish-Lithuanian Commonwealth.

3) The poem by Marcin Paszkowski Posiłek Bellony słowieńskiej... appeals to the Polish nobility and encourages them to take arms. Therefore, a substantial part of the text is dedicated to inspiring knights to perform feats. Paszkowski again resorts to oriental ways of structuring the narrative: Moscow is menacing and frightening, its army far outnumbers the Polish knights - but hasn't it ever happened in history that professional troops, though inconsiderable in number, defeated numerous and disorganised barbarians? The knights should go to a justifiable war and will be rewarded for their spilled blood with the vast eastern areas and unimaginable wealth of the Moscovite usurper Shuysky. Paszkowski assures that it is not the number of the troops but the God's will and the commander's generalship that makes a difference. He illustrates his argument with a range of examples starting from the Bible. This is one of the most vivid examples: to inspire the Polish nobility to take arms against numerous Moscow barbarians Paszkowski suggests following the example of ... Skanderbeg!

${ }^{22}$ M. Kuran, op. cit., 167-168. 
Już on, Skanderbeg, rycerz zacny Boży,

Jak Turkow wielkość bit, brat ich obozy:

Osiemdziesiat tysiac, piacia swych porażat,

Zlych sasiad męstwem i fortelem prazat.

(stanza 112-116)

There is a number of other particularities in the text of the poem by Marcin Paszkowski Posiłek Bellony słowieńskiej... which are even more indicative of his attempt to present the Moscovite state as a new Turkey. The religious aspect is one of them (Paszkowski is adamant in likening the Orthodox to the pagans and Muslims) as well as his assumption about the harm which had already been done by Moscow to the Polish-Lithuanian Commonwealth (for instance, the recent Livonian war and the capture of the Polish diplomats after the death of the False Dmitry). Yet, we consider that the arguments outlined in the article can be sufficient enough to draw researchers' attention to the works by Paszkowski. Studying his legacy requires interdisciplinary efforts which should be made jointly by both linguists, philologists and historians. We are sure that such an approach can lead to new discoveries as far as works by Marcin Paszkowski are concerned.

\section{BIBLIOGRAPHY:}

Danti A., "Utopijny” aspekt literatury antytureckiej we Włoszech $i$ w Polsce w połowie XVI wieku, w: Od "Lamentu świętokrzyskiego" do "Adona". Włoskie studia o literaturze staropolskiej, red. G. Brogi Bercoff, T. Michałowska, Warszawa 1995, 117-138.

Karnauhov D. V., 2009, Moshi unde: развитие представлений о происхождении «московского народа» в польской историографии эпохи Возрождения, „Gumanitarne Nauki v Sibiri" 2009, 2, 10-14.

Krasicki I., Zbior potrzebniejszych wiadomości, porządkiem alfabetu ułożonych, vol. 2, Warszawa - Lwów 1781.

Kuran M., Marcin Paszkowski - poeta okolicznościowy i moralista z pierwszej połowy XVII wieku, Łódź 2012.

Micik A. U., Початки Польськоі держави за хронікою Олександра Гваньіні, „Pam yatki. Arheografichnij Shchorichnik" 2005, 5, 53-84.

Pilipenko V. М., Антитурецький дискурс в політичній думці Речі Посполитої середини XVI - середини XVII cm., avtoreferat disertaciï... kandidata istorichnih nauk: 07.00.02, Kiïv 2009.

Said E., Orientalism, New York 1978.

Sommervogel C., Bibliothèque de la Compagnie de Jésus. Nouvelle édition par Carlos Sommervogel SJ. Bibliographie, vol. 6, Bruxelles - Paris 1895. 
Stachowski M., Marcin Paszkowski's Polish and Turkish dictionary (1615), „Studies in Polish Linguistics" 2013, 8, 1, 45-56.

Wierzbowski T., Biblioteka Zapomnianych Poetow i Prozaików Polskich XVI-XVIII wieku, Warszawa 1886.

Wierzbowski T., Wstęp, Wenecyja. Poemat historyczno-polityczny z końca XVI wieku, Warszawa 1886.

Wolff L., Inventing Eastern Europe: the Map of Civilization on the Mind of the Enlightenment, Stanford 1994.

Załęski S., Jezuici w Polsce, vol. 2, Lwów 1901.

\section{ABSTRACT:}

Macin Paszkowski is a poet first of all famous for his works, connected with Turkey. But he also had other poems, dedicated to different subjects. In this paper we show that non-Turkish works of Paszkowski were influenced by his favorite Oriental theme too. The anti-Moscow poems will serve as the example of a text, which implicitly contains the Turkish theme.

Key words: Marcin Paszkowski, orientalism, Turcyki

\section{NOTA O AUTORACH:}

Elena A. Lisichenok, bachelor of history, master student, Institute of History of St. Petersburg State University, St. Petersburg, Russia, fjernt.land@gmail.com.

Igor A. Prohorenkov, bachelor of history, master student, Institute of History of St. Petersburg State University, St. Petersburg, Russia, ocelot_a@mail.ru. 